As-Syifaa Jurnal Farmasi Juli 2019; 11 (01): 55-60.

ISSN : 2085-4714

\title{
FORMULASI DAN EVALUASI SALEP EKSTRAK DAUN GULMA SIAM (Chromolaena odorata L.) DENGAN VARIASI BASIS SALEP
}

\author{
A.Hasrawati, Yasir Famir, Aztriana, A.Mumtihanah Mursyid \\ Fakultas Farmasi, Universitas Muslim Indonesia, Makassar \\ Email: a.hasrawati@umi.ac.id
}

\begin{abstract}
Siam weed leaves are one of the plants that function as wound medicine. This study aims to produce a stable ointment dosage form. Siamese weed leaf extract is formulated in the form of ointment with a variety of bases consisting of a hydrocarbon base, absorption, water soluble and emulsion. Evaluation of physical stability includes organoleptic testing, homogeneity, $\mathrm{pH}$, dispersion, viscosity and flow properties carried out before and after forced conditions. Forced conditions were carried out with stock storage for 10 cycles at $5^{\circ}$ and $35^{\circ}$. The results of the analysis showed that the viscosity of the preparations in all formulas changed after storage at $5^{\circ}$ and $35^{\circ}$ for 5 days. However, the statistical results show that all formulas did not experience significant changes between before and after the stress condition treatment.
\end{abstract}

Key Words: Siamese weed (Chromolaena odorata L.), ointment, hydrocarbon base, absorption base, water soluble base, emulsion base.

\section{PENDAHULUAN}

Luka merupakan cedera fisik yang mengakibatkan robekan dan kerusakan jaringan kulit. Penyembuhan merupakan proses alami tubuh dalam regenerasi kerusakan jaringan kulit dan epidermal namun tingkat penyembuhannya sangat lambat dan memungkinkan adanya infeksi mikroba. ${ }^{1}$ Salah satu cara yang dapat dilakukan untuk menyembuhkan luka adalah dengan penggunaan bahan alam seperti gulma siam.

Gulma siam (Chromolaena odorata L.) merupakan tanaman obat yang dimanfaatkan masyarakat sebagai obat luka, mengobati infeksi, sakit kepala, diare, sebagai adstringent, antispasmodik, antihipertensi, anti inflamasi dan diuretik. ${ }^{2}$ Daun gulma siam merupakan salah satu jenis tumbuhan dari famili Compositae yang mempunyai kandungan senyawa aktif flavonoid, saponin, tanin, phytat dan glikosida sianogenik yang memberikan pengaruh terhadap kesembuhan luka. Penelitian kesembuhan luka yang menggunakan ekstrak C.odorata yang dilakukan oleh Thang et al., (1998 dan 2001), melaporkan bahwa ekstrak C.odorata memacu proliferasi keratinosit pada human epidermal keratinocyte dengan konsentrasi rendah $(0,1-$ $5 \mu \mathrm{g} / \mathrm{mL}){ }^{13,14}$ Juga telah dilakukan pengujian untuk pengobatan luka pada mencit jantan dengan konsentrasi ekstrak gulma siam 2,5\%, $5 \%$, dan $10 \%$, hasilnya menunjukkan bahwa pada konsentrasi 10\% memberikan efek penyembuhan luka lebih cepat. ${ }^{2}$ Gulma siam juga dapat memberikan efek antibakteri terhadap Staphylococcus aureus dengan MIC $1,25 \mathrm{mg} / \mathrm{mL}^{3}$ Untuk mngoptimalkan manfaat kandungan senyawa daun gulma siam dalam pengobatan luka maka perlu diformulasikan kedalam sediaan farmasi dalam bentuk salep.

Salep merupakan sediaan semisolid yang lunak, mudah dioleskan, dan digunakan 


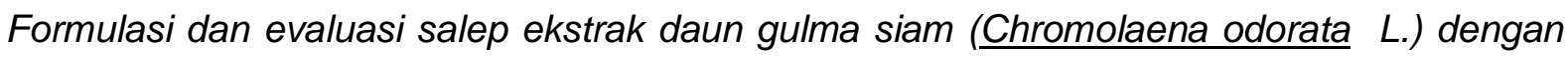
variasi basis salep

sebagai obat luar pada kulit dan membran mukosa. Pelepasan bahan obat dari basis salep sangat dipengaruhi oleh faktor fisikakimia baik dari basis maupun dari bahan obatnya, kelarutan, viskositas, ukuran partikel, homogenitas, dan formulasi. ${ }^{1}$ Pemilihan basis salep yang tepat sangat penting karena basis salep mempengaruhi efek terapeutik dari suatu salep. Salep yang digunakan pada epidermis, mukosa, salep penetrasi atau bentuk cream memerlukan basis salep yang berbeda-beda. Kelarutan dan stabilitas obat di dalam basis, juga sifat luka pada kulit, menentukan pilihan dari pembawa sediaan semipadat. ${ }^{4}$

Tujuan penelitian ini adalah untuk memformulasi sediaan salep dari ekstrak etanol daun gulma siam (Chromolaena odorata L.) yang stabil secara farmasetik menggunakan beberapa variasi basis salep yaitu basis hidrokarbon, basis absorpsi, basis larut air dan basis emulsi.

\section{METODE PENELITIAN}

Sampel yang digunakan dalam penelitian ini adalah daun gulma siam (Chromolaena odorata L.) yang diperoleh dari Buton Sulawesi Tenggara. Penelitian ini dilakukan secara eksperimental laboratorium untuk mendapatkan formula salep ekstrak daun gulma siam yang stabil secara farmasetik menggunakan variasi basis salep.

\section{Alat dan bahan yang digunakan}

Alat-alat yang digunakan yaitualat-alat gelas, climatic chamber ( $\mathrm{ICH} 110 \mathrm{~L} \circledast)$, corong, deksikator, gelas ukur (Pyrex®), kaca arloji, kaca preparat, krus porselin, lumpang dan alu, objek glass, $\mathrm{pH}$ meter (RoHS $\AA$ ), rotary evaporator (IKA® $\AA^{\mathrm{RV}} 10 \mathrm{Basic}$ ), timbangan analitik (Acis $\AA)$, viskometer Brookfield Tipe DV-I Prime. Bahan yang digunakan adalah air suling, alfatokoferol, cera flava, etanol, daun gulma siam, lanolin anhidrat, metil paraben, natrium lauril sulfat, polietilen glikol, propil paraben, propilen glikol, setil alkohol, vaselin kuning.

\section{Prosedur kerja}

\section{Pembuatan ekstrak}

$400 \mathrm{~g}$ serbuk daun gulma siam dimasukan ke dalam wadah berisi etanol $70 \%$ lalu disimpan selama 3 hari. Ekstrak cair disaring hingga diperoleh maserat (Filtrat I) dan residunya diremaserasi dengan prosedur yang sama hingga diperoleh maserat (Filtrat II). Maserat digabungkan (Filtrat I + Filtrat II) dan diuapkan dengan vacum evaporator hingga diperoleh ekstrak kental. Dihitung \%rendemen ekstrak.

\section{Pembuatan salep}

Salep dibuat dengan metode peleburan dan pencampuran. Basis (absorpsi, hidrokarbon, larut air) dimasukkan kedalam cawan porselen lalu dilebur pada penangas air. Basis yang telah meleleh diaduk lalu ditambahkan propil paraben dan alfa tokoferol. Campuran diaduk hingga homogen dalam lumpang. Ekstrak ditambahkan sedikit demi sedikit, sambil diaduk homogen. Salep basis emulsi dibuat dengan melebur fase minyak ( setil alkohol, cera flava, alfatokoferol, dan propil paraben) dan fase air (natrium lauril sulfat, propilen glikol dan metil paraben) secara terpisah. Fase minyak ditambahkan ke dalam fase air dan diaduk sampai terbentuk emulsi. Ekstrak ditambahkan kedalam campuran dan diaduk homogen.

\section{Evaluasi sediaan salep}

Pengamatan organoleptis: Dilakukan pengamatan warna, baud an konsistensi sediaan salep ${ }^{4}$. 


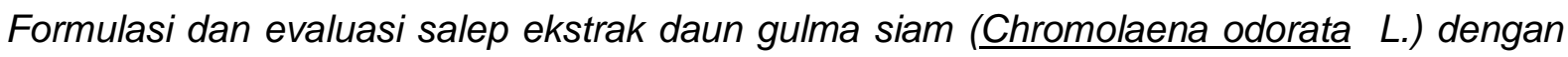
variasi basis salep

Uji homogenitas: Sejumlah salep dioleskan pada plat kaca lalu diamati homogenitasnya. Salep yang homogen ditandai dengan tidak terdapatnya gumpalan pada hasil pengolesan, struktur yang rata dan memiliki warna yang seragam. ${ }^{5}$

Uji pH: 1 gram salep dan diencerkan dengan $10 \mathrm{~mL}$ aquades, kemudian diukur pHnya menggunakan $\mathrm{pH}$ meter ${ }^{6}$.

Pengukur daya sebar: Sebanyak $0,5 \mathrm{~g}$ salep diletakkan diantara dua lempeng objek transparan yang diberi beban $100 \mathrm{~g}$. Pengukuran diameter daya sebar dilakukan setelah salep tidak menyebar kembali atau lebih kurang 1 menit setelah pemberian beban. ${ }^{5}$

Pengukuran viskositas: Viskositas diukur sebelum dan sesudah penyimpanan dipercepat dengan menggunakan viskometer Brookfield dengan spindel 7 pada 50 putaran per menit (rpm). ${ }^{7}$

Penentuan sifat aliran: Sediaan salep diaduk selama 60 detik, lalu dituang ke dalam gelas piala $100 \mathrm{~mL}$, kemudian viskositasnya diukur pada kecepatan $5,10,20,30$ dan $50 \mathrm{rpm}$. Sifat aliran ditentukan dengan mem-buat rheogram hubungan antara shearing stress (tekanan geser) dengan rate of shear (kecepatan geser). Tekanan geser dinyatakan dalam satuan dyne.cm-2, sedangkan kecepatan geser dinyatakan dalam putaran per menit (rpm). ${ }^{7}$

\section{Uji kestabilan}

Evaluasi kestabilan salep dari
sediaan ekstrak etanol daun gulma siam
dengan jenis basis salep yang berbeda
dilakukan sebelum dan sesudah penyimpanan
dipercepat. Penyimpanan dipercepat
dilakukan pada suhu antara $5^{\circ} \mathrm{C}$ dan $35^{\circ} \mathrm{C}$
masing-masing 12 jam selama 10 siklus..$^{8}$

\section{HASIL DAN PEMBAHASAN}

Ekstrak daun gulma siam yang digunakan dalam formulasi sediaan salep diperoleh melalui ekstraksi dengan metode maserasi karena merupakan metode sedrhana dan tanpa pemanasan sehingga kandungan senyawa ekstrak tidak rusak. ${ }^{9}$

Ekstrak daun gulma siam selanjutnya diformulasikan kedalam sediaan salep dengan menggunakan 4 basis yaitu basis hidrokarbon (vaselin kuning), absorbsi (lanolin), larut air (PEG 400 dan PEG 4000) dan emulsi. Pembuatan salep ekstrak daun gulma siam menggunakan metode pencampuran dan peleburan. Setelah salep dibuat dilakukan uji kestabilan dengan kondisi dipercepat yaitu dengan pemaparan suhu $5^{\circ} \mathrm{C}$ dan $35^{\circ} \mathrm{C}$ selama 12 jam sebanyak 10 siklus. Kemudian diamati organoleptik, homogenitas, $\mathrm{pH}$, daya sebar, viskositas dan tipe aliran dari sediaan salep Tersebut. $^{8}$

Pengamatan organoleptik dilakukan pada formula sebelum dan sesudah perlakuan kondisi dipaksakan. Pengamatan organoleptik sesudah kondisi dipaksakan dilakukan untuk mengetahui ada tidaknya perubahan yang terjadi selama penyimpanan.

Hasil pengamatan organoleptik menunjukkan adanya perbedaan warna pada formula salep, karena perbedaan dari masingmasing basis. Sifat organoleptik semua formula salep tidak mengalami perubahan setelah perlakuan stress condition yang menunjukkan sifat stabil sediaan.

$\mathrm{pH}$ pada sediaan topikal diharapkan sesuai dengan $\mathrm{pH}$ kulit yaitu 4,5 - 6,5. ${ }^{10}$ Jika sediaan terlalu asam maka akan memicu iritasi kulit, sedangkan jika sediaan terlalu basa maka mengakibatkan kulit bersisik. 
Formulasi dan evaluasi salep ekstrak daun gulma siam (Chromolaena odorata L.) dengan variasi basis salep

Hasil pengujian $\mathrm{pH}$ menunjukkan bahwa semua formula sediaan memiliki $\mathrm{pH}$ yang sesuai untuk sediaan topikal, meskipun F1 dan F2 mengalami perubahan namun masih berada pada range $\mathrm{pH}$ yang dapat diterima untuk sediaan topikal.

Uji homogenitas mencerminkan tidak terbentuknya partikel-partikel yang memisah atau fase terdispersi terdistribusi secara merata. Hasil uji menunjukkan homogenitas semua sediaan baik sebelum maupun sesudah uji stabilitas.

Uji daya sebar dilakukan untuk mengetahui seberapa besar kemampuan penyebaran salep, karena salep yang baik dapat mudah menyebar dikulit dan nyaman dalam pemakaian. Adapun range daya sebar yaitu $5-7 \mathrm{~cm}^{8,10,11}$

Tabel 1. Hasil Pengamatan Uji Organoleptik Salep Ekstrak Daun Gulma Siam (Chromolaena odorata L.)

\begin{tabular}{|c|c|c|c|}
\hline \multirow{2}{*}{ Formula } & \multirow{2}{*}{ Pemeriksaan } & \multicolumn{2}{|c|}{ Kondisi } \\
\hline & & Sebelum & Sesudah \\
\hline \multirow{3}{*}{$\mathrm{F} 1$} & Bau & Khas ekstrak & Khas ekstrak \\
\hline & Warna & Hijau Pekat & Hijau pekat \\
\hline & Konsistensi & Kental & Kental \\
\hline \multirow{3}{*}{$\mathrm{F} 2$} & $\mathrm{Bau}$ & Khas ekstrak & Khas ekstrak \\
\hline & Warna & Hijau Pekat & Hijau pekat \\
\hline & Konsistensi & Kental & Kental \\
\hline \multirow{3}{*}{ F3 } & $\mathrm{Bau}$ & Khas ekstrak & Khas ekstrak \\
\hline & Warna & Hijau kehitaman & Hijau kehitaman \\
\hline & Konsistensi & Kental & Kental \\
\hline \multirow{3}{*}{$\mathrm{F} 4$} & $\mathrm{Bau}$ & Khas ekstrak & Khas ekstrak \\
\hline & Warna & Hijau kecoklatan & Hijau kecoklatan \\
\hline & Konsistensi & Kental & Kental \\
\hline
\end{tabular}

Tabel 2. Hasil Pengujian pH Salep Ekstrak Daun Gulma Siam (Chromolaena odorata L.)

\begin{tabular}{ccc}
\hline Formula & \multicolumn{2}{c}{$\mathbf{p H}$} \\
\cline { 2 - 3 } & Sebelum & Sesudah \\
\hline F1 & $6,1 \pm 0,05$ & $6,2 \pm 0,05$ \\
F2 & $5,9 \pm 0,05$ & $6,0 \pm 0,05$ \\
F3 & $5,2 \pm 0,02$ & $5,2 \pm 0,02$ \\
F4 & $5,2 \pm 0,02$ & $5,2 \pm 0,02$ \\
\hline
\end{tabular}

Tabel 3. Uji Homogenitas Sediaan Salep Ekstrak Daun Gulma Siam (Chromolaena odorata L.)

\begin{tabular}{ccc}
\hline Formula & & $\mathbf{p H}$ \\
\cline { 2 - 3 } & Sebelum & Sesudah \\
\hline F2 & Homogen & Homogen \\
F3 & Homogen & Homogen \\
F4 & Homogen & Homogen \\
\hline
\end{tabular}

Tabel 4. Uji Daya Sebar Sediaan Salep Ekstrak Daun Gulma Siam (Chromolaena odorata L.)

\begin{tabular}{ccc}
\hline Formula & \multicolumn{2}{c}{ pH } \\
\cline { 2 - 3 } & Sebelum & Sesudah \\
\hline F1 & $5,03 \pm 0,05$ & $5,03 \pm 0,05$ \\
F2 & $5,06 \pm 0,05$ & $5,03 \pm 0,05$ \\
F3 & $5,10 \pm 0,10$ & $5,06 \pm 0,05$ \\
F4 & $4.96 \pm 0,11$ & $4,43 \pm 0,05$ \\
\hline
\end{tabular}


Formulasi dan evaluasi salep ekstrak daun gulma siam (Chromolaena odorata L.) dengan variasi basis salep

Pengukuran viskositas dimaksudkan untuk mengetahui seberapa besar tahanan dari suatu cairan atau sediaan untuk mengalir. Viskositas berkaitan dengan kemudahan pengolesan, karena semakin tinggi nilai viskositasnya maka semakin susah dioleskan pada kulit, begitupun sebaliknya semakin rendah viskositas maka semakin mudah dioleskan pada kulit. ${ }^{12}$
Data di analisis secara statistik menggunakan metode Rancangan Acak Kelompok (RAK). Hasil analisis menunjukkan bahwa viskositas sediaan pada semua formula tidak mengalami perubahan signifikan setelah penyimpanan pada suhu $5^{\circ} \mathrm{C}$ dan $35^{\circ} \mathrm{C}$ selama 5 hari.

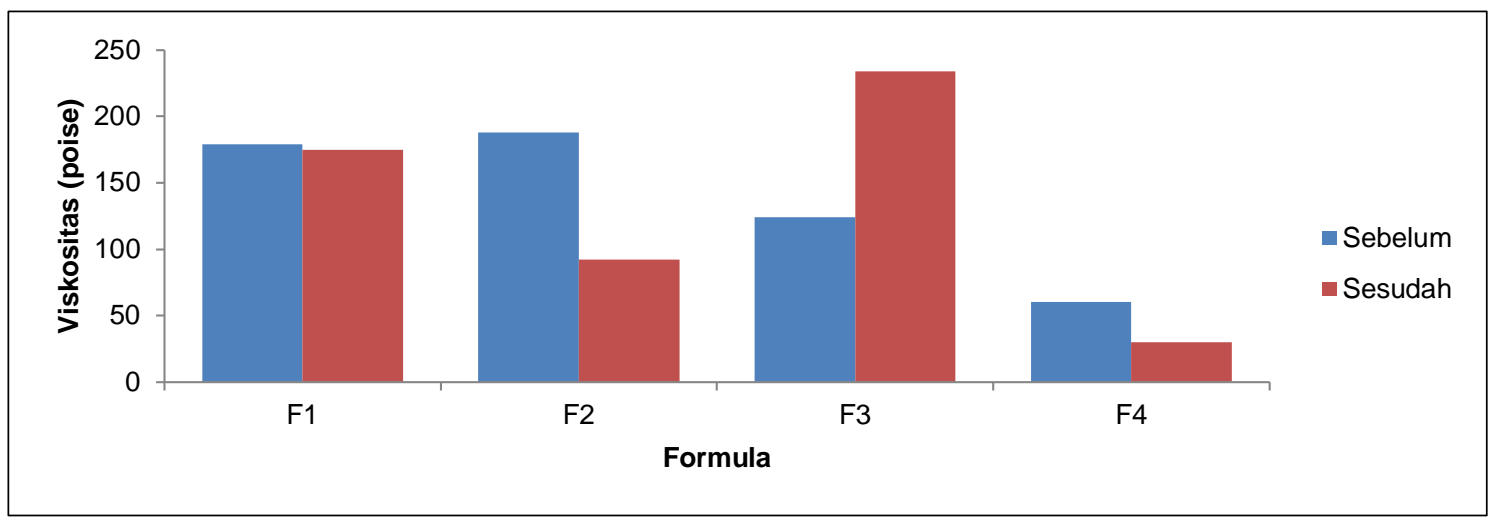

Gambar 1. Histogram viskositas salep ekstrak daun gulma siam
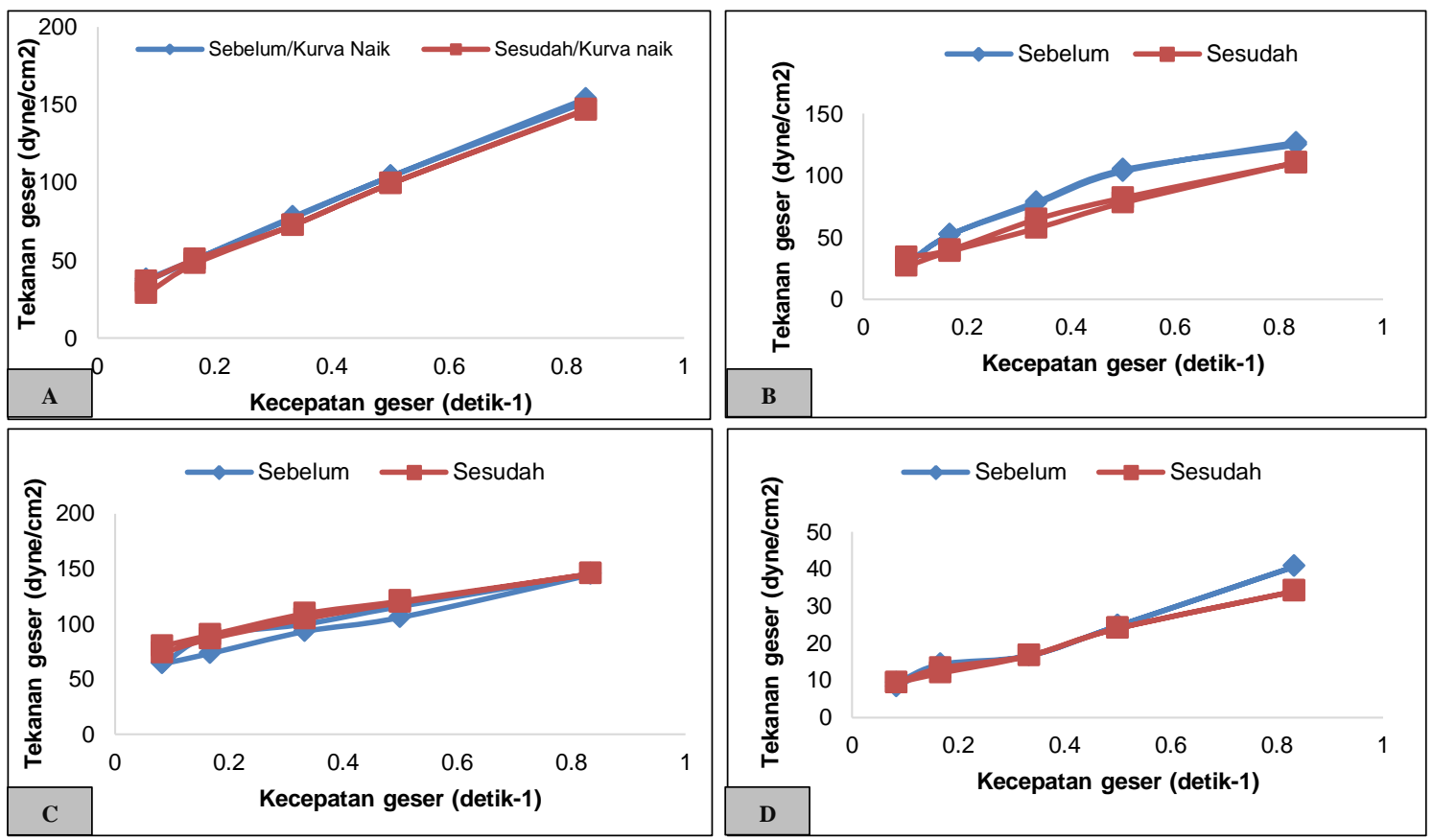

Gambar 2. Rheogram hubungan antara kecepatan geser dan tekanan geser salep ekstrak daun gulma siam sebelum dan sesudah kondisi dipaksakan dengan (A) Basis hidrokarbon; (B) Basis absorbsi; (C) Basis larut air; (D) Basis emulsi. 


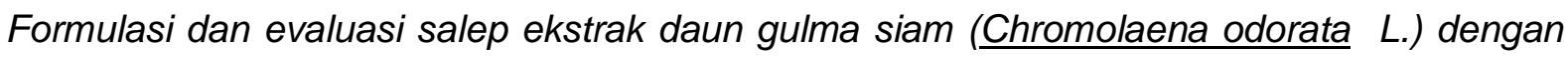
variasi basis salep

Hasil pengujian viskositas dapat dilihat pada gambar 2 yang menunjukkan bahwa terjadi perubahan viskositas sesudah kondisi dipaksakan. Semua formula sediaan memiliki sifat aliran plastis karena kurva yang tidak memotong titik $(0,0)$, tetapi memotong sumbu shearing stress pada nilai yield.

\section{KESIMPULAN}

Berdasarkan penelitian formulasi dan evaluasi salep daun gulma siam (Chromolaena odorata L.) diperoleh kesimpulan yaitu sediaan salep ekstrak daun gulma siam dapat diformulasi dengan basis hidrokarbon, absorbsi, larut air dan emulsi. Semua formula sediaan salep ekstrak daun gulma siam stabil secara farmasetik setelah pengujian stabilitas dengan stress condition.

\section{DAFTAR PUSTAKA}

1. Hernani MY, Mufrod M and Sugiyono $S$. Formulasi Salep Ekstrak Air Tokek (Gekko gecko L.) untuk penyembuhan luka. Majalah Farmaseutik 2012; 8(1):120-124.

2. Yenti R, Afrianti $\mathrm{R}$ and Sandi M. Formulasi Krim Ekstrak Etanol Daun Kirinyuh (Eupatorium odoratum L.) Untuk Penyembuhan Luka. J Scientia 2011; Vol. $3(1)$.

3. Mulyani D. Perbandingan Daya Hambat Ekstrak Etanol Daun Kembang Bulan (Tithonia Diversifolia) Dengan Daun Tekelan (Chromolaena Odorata) Terhadap Bakeri Staphylococcus aureus. Scientia Jurnal Farmasi dan Kesehatan 2017;7(2):77-82.

4. Zulfa E, Prasetyo TB and Murukmihadi M. Formulasi Salep Ekstrak Etanolik Daun Binahong (Anrederacordifolia (Ten.) Steenis) Dengan Variasi Basis Salep. ePublikasi Fakultas Farmasi 2015;12(2):4148.

5. Parwanto ME, Senjaya $H$ and Edy HJ. Formulasi Salep Antibakteri Ekstrak Etanol Daun Tembelekan (Lantana camara L). Pharmacon 2013;2(3).
6. Ali NW. Pengaruh Perbedaan Tipe Basis Terhadap Sifat Fisik Sediaan Salep Ekstrak Etanol Daun Tapak Kuda (Ipomoea pes-caprae (L) Sweet). Pharmacon 2015; 4(3):110-116.

7. Daisa $F$, Andrie $M$ and Taurina $W$. The Effectiveness Test of Oil Phase Ointment Containing Snakehead Fish (Channa striata) Extract on Open Stage II Acute Wounded Wistar Strain Male Rats. Majalah Obat Tradisional (Traditional Medicine Journal) 2017; 22(2):97-102.

8. Banker GS and Rhodes CT. Modern Pharmaceutics, Third Edition. New York: Basel Marcel Dekker Inc, 1995.

9. Puspitasari $A D$ and Proyogo LS. Perbandingan Metode Ekstraksi Maserasi dan Sokletasi Terhadap Kadar Fenolik Total Ekstrak Etanol Daun Kersen (Muntingia calabura). Cendekia Eksata 2017; 2(1).

10. Gennaro AR. Remington's The Science and Practice of Pharmacy (20th ed). Philadelphia: Philadelphia Colage of Pharmacy and Science, 2000.

11. Hoover J. Remington Pharmaceutical Science, 18th Edition. Easton Pennsylvania : Mack Publishing Company, 1990.

12. Sinko PJ. Martin's physical pharmacy and pharmaceutical science, 6th edn. Philladelphia : Wolter Kluwer, 2011.

13. Phan TT, Hughes MA, Cherry GW. Enhanced proliferation of fibroblasts and endothelial cells treated with an extract of the leaves of Chromolaena odorata (Eupolin), an herbal remedy for treating wounds. Plast Reconstr Surg. 1998;101(3):756-65.

14. Thang PT, Patrick S, Teik LS, Yung CS. Anti-oxidant effects of the extracts from the leaves of Chromolaena odorata on human dermal fibroblasts and epidermal keratinocytes against hydrogen peroxide and hypoxanthine-xanthine oxidase induced damage. Burns. 2001;27(4):31927. 